\title{
SYNTHESIS OF LENS PROTEIN IN VITRO \\ V. Isolation of messenger-like RNA from lens by high resolution zonal centrifugation*
}

\author{
A.J.M. BERNS, R.A. DE ABREU, M. VAN KRAAIKAMP, \\ E.L. BENEDETTI** and H. BLOEMENDAL \\ Department of Biochemistry, University of Nijmegen, Nümegen, The Netherlands
}

Received 24 July 1971

\section{Introduction}

Recently Lingrel described the isolation of a $9 \mathrm{~S}$ fraction from mouse reticulocytes which exhibited messenger activity in a cell-free system from rabbit reticulocytes $[1,2]$. Also from other eukaryotic systems RNA with template activity could be isolated. Heywood described the isolation of messenger-like RNA from muscle polyribosomes. He was able to show that with this messenger and $80 \mathrm{~S}$ ribosomes from reticulocy tes a protein could be synthesized which has the characteristics of myosin [3] . An RNA fraction isolated from myeloma appeared to function as template for the synthesis of a mouse Ig light chain in a heterologous cell-free reticulocyte system [4]

The lens is a unique tissue which predominantly produces a class of highly specific proteins: the crystallins. Like mRNA from reticulocyte [5-7] the lens messenger has been reported to be stable [8]. In the present paper a high resolution zonal centrifugation technique is described which allows the isolation of two species of lens messengers differing by a number of criteria from the bulk of ribosomal RNA and tRNA.

* Part of this work has been reported at the EMBO workshop 1970, Nijmegen.

** Guest professor of the Science Faculty of the University of Nijmegen. Permanent address: Institut de Biologie Moléculaire, Faculté des Sciences de Paris, Laboratoire de Microscopie Electronique.

\section{Methods}

Polysomes from 2-3 months old calf lenses were prepared as described earlier $[9,10]$. Polysomes from reticulocytes were prepared according to Allen and Schweet [11]. The polysomes were suspended in

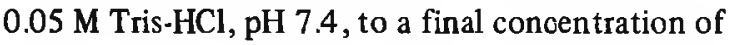
about $6 \mathrm{mg} / \mathrm{ml}$, one tenth volume of $10 \%$ SDS was added and the solution was kept at $37^{\circ}$ for $5 \mathrm{~min}$. One volume of $0.05 \mathrm{M}$ Tris- $\mathrm{HCl}, \mathrm{pH} 7.4$, in $12 \%$ (w/w) sucrose solution was added before pumping the sample into the zonal rotor. For the zonal centrifugation exponential gradients were applied resembling the iso-kinetic gradients described by Price $[12,13]$. These isokinetic gradients can be computed according to the formula:

$$
\frac{r^{2}}{\eta_{\mathrm{m}}}\left(\rho_{\mathrm{p}}-\rho_{\mathrm{m}}\right)=\mathrm{constan} \mathrm{t},
$$

in which

$r=$ the distance to the rotor centre

$\rho_{\mathrm{p}}=$ the density of the particles

$\rho_{\mathrm{m}}=$ the density of the medium at $r$

$\eta_{\mathrm{m}}=$ the viscosity of the medium at $r$.

Zonal centrifugation was performed in a B XXX rotor of IEC. After centrifugation the pattern was automatically scanned at $260 \mathrm{~nm}$ using a Gilford spectrophotometer equipped with a $2 \mathrm{~mm}$ flow cell.

Incubations in a volume of $250 \mu \mathrm{l}$ were performed at $37^{\circ}$ for $30 \mathrm{~min}$. The incubation mixture contained $200 \mu \mathrm{g}$ ribosomes from reticulocytes, preincubated for $90 \mathrm{~min}$ at $37^{\circ}$ according to Cohen [14], $700 \mu \mathrm{g}$ 
100,000 g supernatant protein, $2 \mu \mathrm{g}$ RNA fraction, $20 \mu \mathrm{l} 0.6 \mathrm{M} \mathrm{KCl}$ wash (containing the wash of $300 \mu \mathrm{g}$ polyribosomes, $0.05 \mathrm{M}$ Tris- $\mathrm{HCl}, \mathrm{pH} 7.4,0.15 \mathrm{M} \mathrm{KCl}$, $3.6 \mathrm{mM}$ magnesium acetate, $1 \mathrm{mM}$ ATP, $0.2 \mathrm{mM} \mathrm{GTP,}$ $3.2 \mathrm{mM}$ phosphoenol pyruvate, $5 \mu \mathrm{g}$ pyruvate kinase, $5 \mathrm{mM} \beta$-mercaptoethanol, $0.05 \mathrm{mM}$ L-amino acids except Leu, $0.05 \mathrm{mM}{ }^{14} \mathrm{C}$-DL Leu (specific activity $55.2 \mathrm{mCi} / \mathrm{mmole}$ ). The reaction was stopped by addition of 5\% TCA. The hot TCA precipitable material was counted in a Packard liquid scintillation counter.

The base composition of the isolated RNA fractions was determined according to Katz and Comb [15].

For electron microscopy the RNA fractions were spread on carbon film in the presence of urea and carbon platinum shadowing was applied with an angle of about $15 \mathrm{deg}$.

\section{Results and discussion}

The difficulty in the isolation of messenger RNA from eye lens polysomes is twofold.

(a) It comprises only a small proportion of the total polysomal RNA.

(b) As the molecular weight of lens protein subunits is about 20,000 [16] the sedimentation coefficient of the corresponding mRNA can be expected to

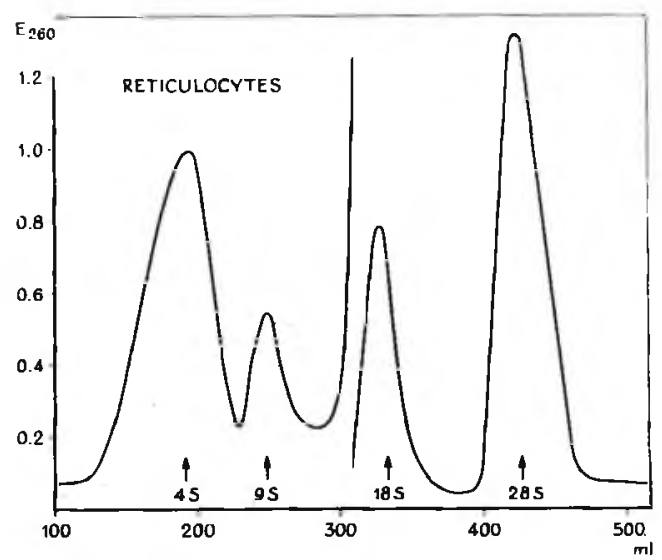

Fig. 1. Zonal centrifugation profile of polysomal RNA from reticulocy tes. Samples varying in volume from 15 to $30 \mathrm{ml}$ were applied. The gradient was isokinetic with the volume. A sucrose gradient from 0 to $26 \%(\mathrm{w} / \mathrm{w})$ has been used. The sample was centrifuged for $5.5 \mathrm{hr}$ at $50,000 \mathrm{rpm}$ and $2^{\circ}$ in a $\mathrm{B}$ XXX zonal rotor of an IEC centrifuge.

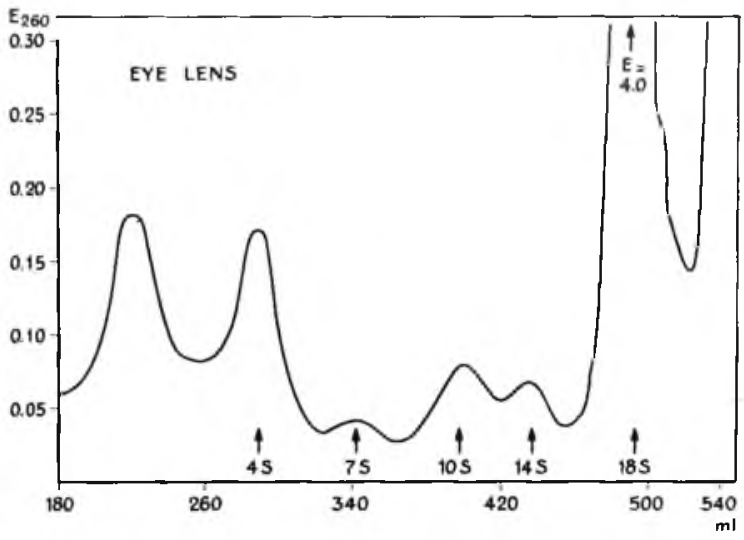

Fig. 2. Zonal centrifugation profile of polysomal RNA from lens polyribosomes. Centrifugation was performed for $15 \mathrm{hr}$ at 50,000 rpm and at $2^{\circ}$ in an exponential sucrose gradient in $0.05 \mathrm{M}$ Tris-HCl, pH 7.4, (0-28\% sucrose w/w). The gradient was constructed by pumping $37 \%$ sucrose in a mixing chamber containing $300 \mathrm{ml}$ buffer. $50 \mathrm{ml}$ of the gradient with $100 \mathrm{ml}$ buffer was used as overlayer. The sample volume varied from 15 to $30 \mathrm{ml}$.

be about $11 \mathrm{~S}$ so that it may be masked by the bulk of ribosomal RNA.

High resolution zonal centrifugation appeared to be a very useful tool for the solution of this problem.

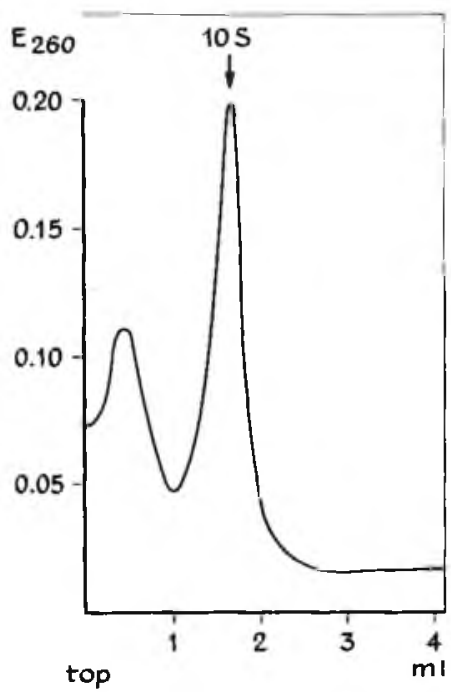

Fig. 3. Recentrifugation of the $10 \mathrm{~S}$ fraction. Recentrifugation of the $10 \mathrm{~S}$ fraction was performed for $4 \mathrm{hr}$ at $6^{\circ}$ in a SB 405 rotor of the IFC ultracentrifuge with a $5-19.1 \%$ exponential sucrose gradient. 


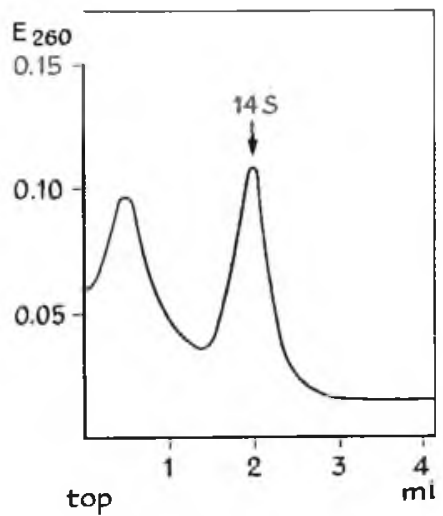

Fig. 4. Recentrifugation of the $14 \mathrm{~S}$ fraction. Conditions as mentioned under fig. 3 .

We used exponential gradients resembling the isokinetic gradients described in the literature [13] but somewhat steeper to prevent zone broadening.

In order to check our method RNA from reticulocyte polysomes was separated (fig. 1). In fig. 2 it is clearly shown that with RNA extracted from lens polysomes even higher resolution can be achieved. The homogeneity of the lens "messenger" fractions was demonstrated by recentrifugation in a swinging bucket rotor (fig. 3 and 4).

The activity of the fractions was tested in the reticulocy te cell-free system (table 1). It can be seen that crude initiation factors obtained from polysomes after washing with $0.6 \mathrm{M} \mathrm{KCl}$ enhance the stimulation although there is some variation in the different experiments, possibly caused by the instability of either one or more initiation factors. The addition of $18 \mathrm{~S}$
Table 1

Stimulation of amino acid incorporation by RNA fractions from lens and reticulocyte polysomes.

\begin{tabular}{|c|c|c|}
\hline \multirow{2}{*}{ Added fraction } & \multicolumn{2}{|c|}{$\begin{array}{l}\text { Incorporation of Leu } \\
\text { (pmoles) }\end{array}$} \\
\hline & -KCl Wash & $+\mathrm{KCl}$ Wash \\
\hline - & 2.7 & 3.3 \\
\hline $18 \mathrm{~S}$ & 3.3 & 3.3 \\
\hline $9 \mathrm{~S}$ reticulocy tes & 6.5 & 7.6 \\
\hline $10 \mathrm{~S}$ lens & 7.6 & 12.2 \\
\hline $14 \mathrm{~S}$ lens & 7.6 & 10.7 \\
\hline
\end{tabular}

Assay conditions as reported under Methods.

RNA instead of the messenger-like RNA species does not result in an increase of the amino acid incorporation excluding the possibility of non-specific stimulation by high molecular weight RNA.

In table 2 the base composition of the different RNA fractions isolated from eye lens poly somes is summarized. It appears, that the $18 \mathrm{~S}$ and $28 \mathrm{~S}$ fractions have values expected for ribosomal RNA whereas the $10 \mathrm{~S}$ and $14 \mathrm{~S}$ fractions exhibit a more "DNA"like base composition.

We obtained similar results with RNA isolated from RNP particles derived from polysomes by EDTA treatment in magnesium-free medium. A striking observation was that in addition to the small and large ribosomal subunits two discrete RNP fractions could be isolated with sedimentation coefficients of about $16 \mathrm{~S}$ and $21 \mathrm{~S}$ respectively. From the $16 \mathrm{~S}$ particle consistently the $10 \mathrm{~S}$ "messenger" was obtained whereas the $14 \mathrm{~S}$ RNA represented the major component of the $21 \mathrm{~S}$ particle. The active fraction

Table 2

Nucleotide composition of messenger-like RNA.

\begin{tabular}{|c|c|c|c|c|c|}
\hline \multirow[t]{2}{*}{ RNA } & \multirow[t]{2}{*}{ AMP } & \multirow[t]{2}{*}{ UMP } & \multirow[t]{2}{*}{ GMP } & \multirow[t]{2}{*}{$\mathrm{CMP}$} & \multirow{2}{*}{$\frac{\mathrm{GMP}+\mathrm{CMP}}{\mathrm{AMP}+\mathrm{UMP}}$} \\
\hline & & & & & \\
\hline $18 \mathrm{~S}+28 \mathrm{~S}$ & $19.4 \pm 0.9$ & $18.3 \pm 0.5$ & $32.0 \pm 0.6$ & $30.3 \pm 0.7$ & 1.65 \\
\hline $10 \mathrm{~S}$ & $18.9 \pm 0.7$ & $30.3 \pm 1.0$ & $28.9 \pm 2.2$ & $21.9 \pm 1.1$ & 1.03 \\
\hline \multirow[t]{3}{*}{$14 \mathrm{~S}$} & $19.2 \pm 0.8$ & $30.4 \pm 0.6$ & $30.4 \pm 0.9$ & $20.0 \pm 0.4$ & 1.02 \\
\hline & \multirow{2}{*}{ dAMP } & \multirow{2}{*}{ dTMP } & \multirow{2}{*}{ dGMP } & \multirow{2}{*}{ dCMP } & $\mathrm{dGMP}+\mathrm{dCMP}$ \\
\hline & & & & & $\mathrm{dAMP}+\mathrm{dTMP}$ \\
\hline Calf thymus DNA [16] & 27.4 & 29.5 & 22.4 & 20.7 & 0.78 \\
\hline
\end{tabular}

The values are the averages of 3 to 6 determinations. Standard errors were calculated using the formula: $\sqrt{\Sigma(x-\bar{x})^{2} / N \times(N-1)}$. 


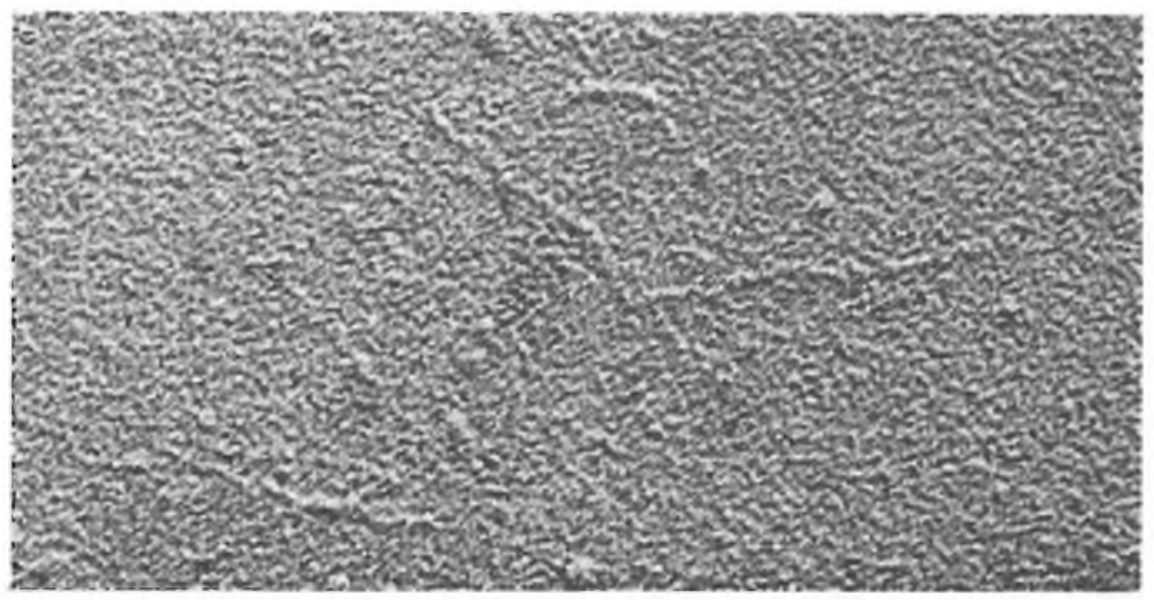

Fig. 5a. Electron micrograph of lens 'messenger' RNA fractions. Magnification 100,000 . The major strand is apparently built up by shorter segments joined together.

has also been investigated by electron microscopy with different spreading techniques including simple spreading of the material on carbon films (fixation with $1 \%$ glutaraldehyde) and the Kleinschmidt [17] method for single stranded RNA [18].

The presence of stranded material could clearly be demonstrated in the $10 \mathrm{~S}$ fraction. The thickness of the "threads" measured in the shadowed preparations is consistent with the average thickness reported for single stranded RNA.

The length of the threads varies from 0.3 to $1 \mu \mathrm{m}$ (fig. 5a). Occasionally longer strands have been found which possibly are resulting from association of the smaller pieces (fig. 5b). In fact the longer filaments show different width and branching.

Whether the stimulation by these RNA fractions results in de novo synthesis of a specific protein has to be elucidated. These experiments are in progress. Meanwhile we were able to show that the $14 \mathrm{~S}$ messenger directs the synthesis of the $\alpha$ crystallin $\mathrm{A}_{2}$ chain in heterologous cell-free systems.

\section{Acknowledgements}

The present investigations have partly been carried

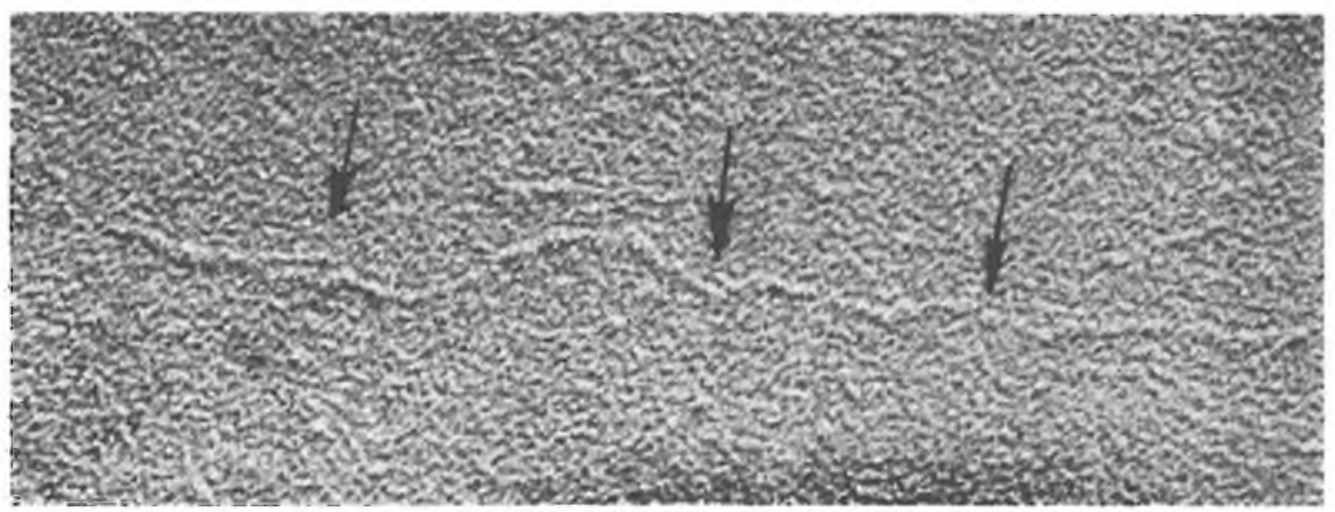

Fig. 5b. The same preparation showing a longer strand apparently built up by shorter segments. (The arrows indicate overlapping regions.) 
out under auspices of the Netherlands Foundation for Chemical Research (SON) and with financial aid from the Netherlands Organization for the advancement of Pure Research (ZWO).

\section{References}

[1] M.I. Evans and J.B. Lingrel, Biochem. 8 (1969) 3000.

[2] R.E. Lockard and J.B. Lingrel, Biochem. Biophys. Res. Commun. 37 (1969) 204.

[3] S.M. Heywood, Nature 225 (1970) 696.

[4] J. Stavnezer and R.C.C. Huang, Nature 230 (1971) 172.

[5] P.A. Marks, E.R. Burker and D. Schlessinger, Proc. Natl. Acad. Sci. U.S. 48 (1962) 2163.

[6] P.A. Marks, C. Willson, J. Kruh and F. Gros, Biochem. Biophys. Res. Commun. 8 (1962) 9.

[7] A. Burny and A. Chantrenne, Biochim. Biophys. Acta 80 (1964) 31.

[8] J. Papaconstantinou, A.J. Steward and P.V. Koehn, Biochim. Biophys. Acta 114 (1966) 428.
[9] H. Bloemendal, J.G.G. Schoenmakers, A. Z weers, R. Matze and E.L. Benedetti, Biochim. Biophys. Acta 123 (1966) 217.

[10] J.G.G. Schoenmakers, A. Zweers and H. Bloemendal, Biochim. Biophys. Acta 145 (1967) 120.

[11] E.H. Allen and R.S. Schweet, J. Biol. Chem. 237 (1962) 760.

[12] C.A. Price, personal communication.

[13] C.A. Price, in: Manometric Techniques, 5 th Ed.. eds. W.W. Umbreit et al. (Burgess, Madison, 1971).

[14] B.B. Cohen, Biochem. J. 110 (1968) 231.

[15] S. Katz and D.G. Comb, J. Biol. Chem. 238 (1963) 3065 .

[16] W.S. Bont, J.F. Jongkind, J.H. Wisse and H. Bloemendal, Biochim. Biophys. Acta 59 (1962) 512.

[17] A.K. Kleinschmidt, D. Land, D. Jacherts and R.K. Zahn, Biochim. Biophys. Acta 61 (1962) 857.

[18] N. Granboulan, J. Huppert and F. Lacour, J. Mol. Biol. 16 (1966) 571.

[19] E. Chargaff, in: The Nucleic Acids Vol. I (Academic Press, New York, 1955) p. 354. 